\title{
Study on land reclamation of soil dump and tailing pond in mining area
}

\author{
Wencai Wang ${ }^{1, \mathrm{a}}$, Jingwen Zhao ${ }^{2, \mathrm{~b}^{*}}$, Peng $\mathrm{Fu}^{2, \mathrm{c}}$ \\ ${ }^{1}$ Institute of Mining and Coal, Inner Mongolia University of Science and Technology, Baotou 014010, \\ China \\ ${ }^{2}$ Research Institute of Mining, Inner Mongolia University of Science and Technology, Baotou 014010 , \\ China \\ awencai99999@163.com, bzhaojingwen0122@126.com, cfupeng0816@sina.com
}

Key words: mine; dump; tailing; reclamation technology

Abstract. The plant disposition pattern of the soil dump and tailing pond in a metal mine is defined as the model of grass, shrub and arbor, on which based the restrictive factors of land reclamation in mining area, the optimal allocation principle of vegetation and the experimental research on field. The method of land reclamation in the dump of mining area is about dumping and reclamation simultaneously. The thickness of the land cover of land reclamation is about $50 \mathrm{~cm}$. The reclamation method of tailing pond is to implement measures of engineering obstruction by covering surface soil stripped first, and then using excrement of animals like sheep and cow as organic fertilizer to improve the soil. In the end, the suitable vegetation is planted.

\section{Introduction}

The heavy metal elements in the mine dump waste will cause serious pollution to the soil, ground water and underground water by weathering leaching process. After the tailings pond closed, the water evaporation and dries up in tailing pond, if not reclamation timely, a serious sand storm would be produced in windy weather, which causes atmospheric pollution. Therefore, it is necessary to pay attention to land reclamation of soil dump and tailing pond in mining area.

In the land reclamation, the main factor that restrict the vegetation restoration is the serious wind erosion[1]. Therefore, the major reclamation engineering measures in dump are topsoil stripping cover, soil fixation and sand prevention. The measures of soil fixation and sand prevention can be achieved by setting artificial straw and grass grid, which restraining water and soil loss effectively[2].

The reclamation of tailing pond generally includes three parts, the reclamation project, the biological vegetation project and the later stage maintenance project[3].

It is necessary to analyze the soil condition in the land reclamation. In order to make the physical and chemical properties of the soil more suitable for the growth of vegetation, there are three methods can be used including green manure, organic fertilizer, chemical modifier[4]. Studies have shown that the metal mobility can be reduced by planting metal tolerant plants in heavy metal contaminated land, and heavy metals can be absorbed by planting of hyperaccumulator plants[5]. Practice shows that the application of tolerance plants and the application of organic manure on the mining land reclamation have significant effect[6-8].

\section{General situation of study area}

A multi metal open pit is the research object, which height above sea level is $1400 \mathrm{~m} \sim 1800 \mathrm{~m}$ and 
relative elevation is $10 \sim 30 \mathrm{~m}$. The mining area belongs to hilly terrain, the relative altitude is very small and the topographic relief amplitude is gentle. The climate type of the open pit belongs to the highland continental climate. The highest rainfall in a year was $251.7 \mathrm{~mm}$ and the minimum rainfall was $141.4 \mathrm{~mm}$. The maximum temperature in a year was 35.2 degrees Celsius, the minimum temperature was -34.6 degrees Celsius, and the annual average temperature of the year was 7.4 degrees Celsius. The drought in the area is significant, because the amount of rainfall is smaller than that of evaporation. The perennial wind direction of the metal open pit was the northwest wind and the southwest wind, the maximum wind speed was $23.3 \mathrm{~m} / \mathrm{s}$ and the earthquake intensity can be estimated as 6 degrees.

\section{General situation of soil dump in research area}

The choice of dumping site is outside of the ultimately state of the open pit mining field, and the distance between them is $100 \mathrm{~m}$. According to the different rock properties, the barren rocks are stacked separately. The stage height of the dump is $40 \sim 60 \mathrm{~m}$, the safety platform width of each step is not less than $20 \mathrm{~m}$. The angle of final pit slope is $30^{\circ}$ and the maximum discharge height is $80 \sim 100 \mathrm{~m}$. The sector drainage technology is used in the soil discharging machine operation in the dump. Stope late deep peeling of rare earth, dolomite and waste rock are transported to the dumping ground by combined transportation mode of car-crusher-edge tape machine, and then abandoned them according to the different types.

\section{General situation of tailings reservoir in study area}

The dam body of the tailings pond is consisted of ground slag, which width in east-west direction is about $3.2 \mathrm{~km}$, length in north-south direction is about $3.5 \mathrm{~km}$. The circumference of the dam is 11.5 $\mathrm{km}$, the tailing pond area is about $12 \mathrm{~km}^{2}$. The bottom elevation of the dam is about $1025 \mathrm{~m}$, the elevation 1045 meters, the crest elevation of the dam is about 1045 meters. Tailing's reservoir capacity can be estimated as 68830000 cubic meters. At present, tailings dam has 150 million tons of tailings, including 9.3 million tons of rare earth and 70 thousand tons of thorium. Based on expert argumentation, there is a conclusion that the Final height of the dam can be reach $1065 \mathrm{~m}$ because the north of the dam body is higher than the south and the south dam should be heightened. The particle of tailings are very small, the minimum of them are only a few microns, which polluted the air by wind. The water flows out from the tailings dam, the dam foundation and the base of the bank. Infiltration of water flows into the lower reaches of the shallow water and causes pollution, the pollution scope is about $7.5 \mathrm{~km}^{2}$ and diffusion speed is $30 \mathrm{~m}$ per year. The range of soil pollution in downstream is about $20 \mathrm{~km}^{2}$, which aggravated soil salinization and lead to contamination of water soluble fluoride and total fluoride.

\section{Analysis on the limiting factors of land reclamation in the study area}

\section{Shortage of water resources}

The study area is located on the regional watershed, there is no perennial surface water flow in the region, only 3 inland intermittent rivers distribute in the south, northwest and north of the mining area. Therefore, there is no protection water for the vegetation recovery in the dump and the tailings.

In addition, the amount of water produced during mining is few and not easy to concentrate, so it also can not be used in the land reclamation. The climate of this area belongs to highland continental climate, the annual rainfall is smaller than the evaporation, the average annual rainfall is $238.3 \mathrm{~mm}$ and the average amount of evaporation is $2743.5 \mathrm{~mm}$. The survival rate of vegetation in reclamation is low because of the lack of moisture. 


\section{Lack of suitable plant species}

Lacking of suitable plant species is the major limiting factor. There are complex factors caused the vegetation of artificial introduction is difficult to survive in the early stage of the soil. The factors including shallow soil, lack of nutrients, lack of water resources, soil pollution and so on. Currently in the artificial intervention, plants with good suitability in mining area are hippophae rhamnoides, caragana microphylla, clove, medicago sativa, astragalus adsurgens, elymus, bluegrass, etc. The study area can not form a stable, integrated ecosystem.

\section{Heavy metal pollution in the tailing}

The iron ore belongs to the REE-Nb-Fe deposit. There are tailings remaining after beneficiation, the tailings are kept in tailings pond directly. Tailings waste is usually including mixed soil, gravel with different particle sizes and weathering products, etc., which has big difference with normal soil. The content of organic matter, nitrogen and phosphorus in tailings pond is very low, and only $20 \%$ to $30 \%$ of the average background value of the soil. Tailing leaching liquid generally contains excessive heavy metal elements. These harmful elements will rise to the surface by the soil capillary action. It is difficult for normal plants to survive and grow without effective protective measures.

\section{Study on land reclamation technology in the study area}

Land reclamation technology is including engineering measures, biological measures, experimental study and reclamation technology.

\section{Engineering measures}

Topsoil stripping

Topsoil stripping is the first step and the key step of dump reclamation. Topsoil stripping will provide a foundation for soil reconstruction. Meanwhile, it prevents plenty of topsoil from losing. Topsoil stripping can be stripped by excavators. Soil thickness is $30 \mathrm{~cm}$. Using small bulldozer bulldoze the stripped topsoil to be a piece of scattered pile soil field, to keep the ventilation permeability of topsoil and to prevent soil quality decline.

Land leveling

Land leveling project is the pre-work of making damaged land to be available land. The purpose is to achieve the implementation of biological measures by land leveling, conducive to drainage, improved soil , and to meet the needs of vegetation on the terrain[9]. The implementation area land leveling project is collapse pit and waste dump. Collapse pit after filling and accumulation of waste dump, the surface of the rock is mainly composed of large and coarse clastic rocks. The rock is loose, the pore is big, the permeation of water is easy. Land leveling area need to be levelled and compact by big bulldozers. Meanwhile, form a certain slope angle near the side of slope, in order that water can flow itself.

\section{Biological measures}

Soil improvement

The thickness of the surface layer soil of the mining area is thinner. The soil source under the surface layer is mostly low organic matter content, and lack of the necessary nutrient elements of sandy soil. Therefore, it is an important measure to improve soil fertility and improve the land reclamation of metal mine. In view of the problem of low soil nutrient content, the soil is improved, the effective method is to use organic fertilizer to improve soil organic matter. Because the mining area is located in the grassland area, the feces of livestock can be used as the main component of organic fertilizer. Due to the economy and efficiency, this method can be used in a large area of dump platform and slope. 
Optimal allocation of vegetation

The optimal allocation of vegetation should follow the following principles [10]

(1) Adaptive principle: Plant communities should be adapted to local natural conditions and site conditions.

(2) Plant optimization principle: The selected plants should be in accordance with the selection criteria of pioneer plants or suitable plants.

(3) Stability and sustainable development principles: The allocation of community should conform to the law of natural succession of vegetation. It should be beneficial to the stability and sustainable development of the artificial ecological community.

(4) Benefit priority principle: The ecological benefit, economic benefit and social benefit should be considered in the plant disposition, the 3 benefits in the near, medium and long-term mutual transformation.

(5) Minimum risk principle: Investment is small, the loss caused by failure is small.

In summary, natural conditions and site conditions should be considered in the selection of plants.

The plant disposition should be in accordance with the law of natural succession of vegetation to achieve favorable ecological benefits. Ensure the sustainable development of the ecological community.

The short term and long term effects should be taken into consideration in the plant varieties planted by the dump and the tailing pond. Herbaceous plants can effectively control the initial soil erosion, but due to climate drought and other reasons, herbaceous will be degraded in 1 3 years. Shrubs and trees can provide long-term or permanent protection to the ground. But it is not good to control the erosion of the soil in the early stage. Therefore, the grass, shrub and tree model is the best plant disposition scheme of soil dump and tailings pond.

\section{Experimental study}

At present, our country has made great progress in the land reclamation technology of metal mine, and the practical measures have been mastered. Such as stabilization process, soil reconstruction technology, vegetation screening technology and vegetation planting methods, etc. In order to ensure the efficiency of reclamation, land reclamation experiment research must be on line, accumulating experience for later stage of land reclamation.

Test sites need 2 places, respectively include soil dump vegetation restoration test site and the test site for restoration of biological diversity of tailing pond. The test site is divided into different test areas. Cover different soil in different test plot, planting different plants, monitoring the changes of soil physical and chemical properties, germination percentage of vegetation, plant growth height, vegetation coverage and biomass, etc. Through the evaluation and summary of the reclamation experiment in this area, the technology of soil improvement in this area will be obtained, to obtain a pioneer plant species with tolerance to poor environment, to master the technology of the vegetation, the planting technique and the method of tending management in this area.

\section{Reclamation technology.}

Land reclamation technology in the study area

The dumping place piling dolomite and niobium ore contain rare and rare earth elements. Soil and plant measures are not taken in the field of useful rock dump. Restoration of vegetation measures in waste rock dump. The reclamation technology of dump site is shown in Figure 1, it contains:

(1) Reclamation and soil at the same time, and the excess topsoil stripping will be transport, row piles, in preparation for reclamation. The thickness of the land cover of land reclamation is about $50 \mathrm{~cm}$. 
(2) The surface of the upper part of the platform of dump reclamation should be smooth, have a certain slope (Not less than $0.5 \%$ ) and build ditches, to reduce water and soil losing.

(3) Under the conditions permit, dump slope reclamation gentle slope is 28 degrees -35 degrees. Spraying mud on slope, then spraying grass or vegetation, or digging planting scales, to reduce water and soil losing.

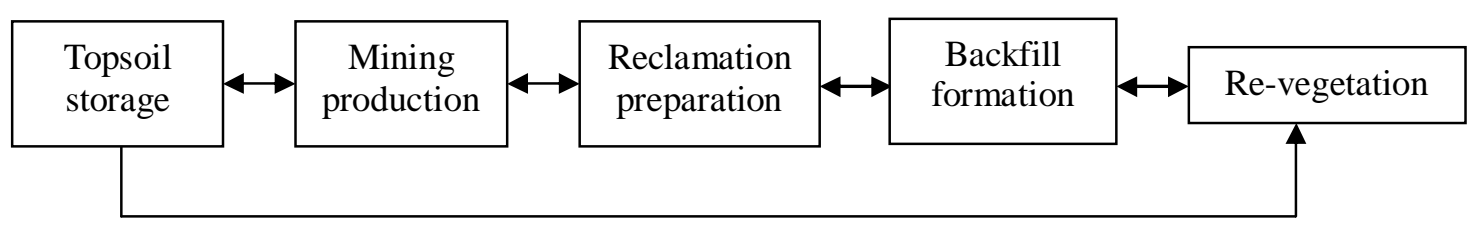

Fig.1 The process flow chart of reclamation process of dump

Reclamation technology of tailings in study area

Tailings pond is the key point of land reclamation of metal mine, Land pollution and pressure belong to the type of land destruction of tailings, but the land pollution is more serious. The open piled tailings containing waste residue that screened by other associated ore and ore slag, the content of heavy metals in the waste residue is usually very high. The poisonous and harmful elements of tailings penetrated the soil easily after rain erosion, leaching and so on. The results not only make the natural colonization of plants on the tailings is extremely difficult, and cause the surrounding organisms to have been poisoned by the heavy metal losing with the rain water. Therefore direct soil covering is not an effective measure for reclamation.

The reclamation for polluted land is generally divided into two processes:

( 1 )Engineering barrier measures. The soil function of tailing pond is almost non-existent, coupled with heavy metal pollution and toxic chemicals and harmful gases, vegetation is difficult to grow. Engineering barrier measures are necessary such as putting a barrier material or buffer material on soil. There are two main objectives of the engineering project:

$\square$ To prevent the spread of pollutants.

Taking engineering barrier can be timely blocking tailings oxide with air and water contact, reduce oxidative reductive reaction, prevent the generation and diffusion of more toxic and harmful pollutants, the scope and extent of contamination are controlled to minimum as far as possible.

The mine can be taken measures of covering the topsoil stripping, this measure can stop the water and oxygen into the interior of the tailings as soon as possible and prevent the proliferation of the leaching liquid of pollutants into the environment. The heart of the soil layer from the hillside has a certain viscosity, which could achieve a better barrier effect.

$\square$ On the barrier materials, the other materials which could improve the soil matrix can be added to create a more favorable environment for growth of vegetation. Lime can increase the $\mathrm{pH}$ value of the substrate and decrease the activity of heavy metals. Phosphate rock can adsorb heavy metals and reduce the effectiveness of heavy metals. Taking into account that the mining area is located in the grassland area, the manure of sheep, cattle and other livestock can be used as organic fertilizer to improve the tailings reclamation soil.

( 2 )Using biological measures to establish vegetation growth layer. Pollution has been preliminary control after applying engineering measures, but is still not stable enough. The phytoremediation technology can be used to remove heavy metals in soil environment. This technology is basis on the 
theory of the toleration and excessive accumulation of some heavy metals by plants. The plants having resistant to heavy metals and acid should be planted combined with local season, so the primary vegetation growth layer is established, with improvement of vegetation growth environment within the next few years, the native species of trees and shrubs could be planted to complete vegetable layer and to achieve the best effect of reclamation. The shrubs can be planted in the project area including Hippophae rhamnoides, Caragana microphylla, clove, and the grass species including Medicago sativa, Astragalus adsurgens, Elymus dahuricus, bluegrass etc.

\section{Conclusions}

(1) According to the characteristics of the mining area, the climate and environment characteristics, the limiting factors of the land reclamation in the mining area are mainly the shortage of water resources, the suitable species and the heavy metal pollution in tailing pond.

(2) The process of soil dumping and land reclamation in the mining area is carried out simultaneously. The excess topsoil stripping will be transport, row piles, in preparation for reclamation. The thickness of the land cover of land reclamation is about $50 \mathrm{~cm}$

(3) The mine tailings use covered with topsoil tripping engineering measures to prevent pollution from spreading. Then the feces of livestock can be used as the main component of organic fertilizer. Planting suitable vegetation on the reclaimed soil of the mine tailings.

\section{Acknowledgements}

This work was financially supported by Program of the Inner Mongolia Science and Technology Department ( 20140711-2 ) .

\section{References}

[1] TAI Pei-dong, SUN Tie-heng, JIA Hong-yu, etc. Restoration for Refuse Dump of Open-Cast Mine in Steppe Region[J].Journal of Soil and Water Conservation, 2002,16(3):90-93.

[2]LIU Chun-lei, WANG Jin-man, BAI Zhong-ke, etc. Analysis of Land Reclamation Technologies for Surface Coal Mine in Arid Grassland[J].METAL MINE, 2011(5): 154-157.

[3]WEI Bo. Study on Evaluation Standard, Statement Request in Coal Mine and Key Contents of Land Reclamation Project[M].Beijing: China University of Geosciences for Master Degree, 2008.

[4]ZHAO Zhong-qiu, ZHOU Zeng-ke, LIANG Deng, etc. Contamination Control and Ecological Reclamation Design in Land Reclamation of Metal Mine-Case Study of Gaocheng Zinc-Lead Mine, Yun'an County, Guangdong Province [J]. Environmental Science\&Technology,2010,33(12F):106-110.

[5]HUANG Ming-hong, LUO Yong-ming. Land Restoration and Ecological Restoration in Mining Area [J].Acta Pedologica Sinica, 2003 , 40(2): 161-169.

[6] Lan C Y, Shu W S, Wong M H. Reclamation of Pb/Zn mine tailings at Shaoguan, Guangdong Province, PRC: the role of river sediment and domestic refuse. Biores , Tech. , 1998, 65: 117 124.

[7]Ye $\mathrm{Z} \mathrm{H}$, Wong $\mathrm{J} \mathrm{W} \mathrm{C}$, Wong $\mathrm{M} \mathrm{H}$, et al, Lime and pig manure as ameliorants for revegetating lead/zinc mine tailings: A greenhouse study. Biores.Tech. ,1990,69: 35 43. 
[8] Ye Z H, Wong J W C, Wong $\mathrm{M} \mathrm{H}$, et al. Revegetation of $\mathrm{Pb} / \mathrm{Zn}$ mine tailings, Guangdong Province, China. Restor.Ecol. ,2000, 8: 87 92.

[9]YANG Jun-peng, DAI Hua-yang, ZHAO Xi, etc. Study on the technology of land rehabilitation of metal mine area in alpine region of northwestern Yunnan: a case study of taking Pulang copper mine area[J].China Mining Magazine, 2015 , 24 (12):66-69.

[10] LI Xiao-dan, ZHANG Zheng-fu. Analysis of land reclamation in mine dump of Fuxin[J]. Journal of Liaoning Technical University (Natural Science), 2009 , 28: 251-253. 